\title{
Morphometrics of Amblyomma mixtum in the State of Veracruz, Mexico
}

\author{
Mariel Aguilar-Domínguez ${ }^{1}$, Dora Romero-Salas ${ }^{1, * \mathbb{D}}$, Sokani Sánchez-Montes ${ }^{2}$, Ricardo Serna-Lagunes ${ }^{3} \mathbb{D}$, \\ Greta Rosas-Saito ${ }^{4}$, Anabel Cruz-Romero ${ }^{1}$ and Adalberto A. Pérez de León ${ }^{5,6}$
}

1 Laboratorio de Parasitología, rancho “Torreón del Molino", Facultad de Medicina Veterinaria y Zootecnia, Universidad Veracruzana, Veracruz 91697, Mexico; marieaguilar@uv.mx (M.A.-D.); anabcruz@uv.mx (A.C.-R.)

2 Facultad de Ciencias Biológicas y Agropecuarias Región Tuxpan, Universidad Veracruzana, Tuxpam 92870, Mexico; danisanchez@uv.mx

3 Laboratorio de Bioinformática y Bioestadística, Facultad de Ciencias Biológicas y Agropecuarias, Universidad Veracruzana, Córdoba 94945, Mexico; rserna@uv.mx

4 Red de Estudios Moleculares Avanzados, Instituto de Ecología, Xalapa 91073, Mexico; greta.rosas@inecol.mx

5 USDA-ARS Knipling-Bushland U.S. Veterinary Pest Genomics Center and Livestock Insects Research Laboratory, Kerrville, TX 78028, USA; beto.perezdeleon@usda.gov

6 USDA-ARS San Joaquin Valley Agricultural Sciences Center, Parlier, CA 93648, USA

* Correspondence: dromero@uv.mx; Tel.: +52-(229)-9342075

check for updates

Citation: Aguilar-Domínguez, M.; Romero-Salas, D.; Sánchez-Montes, S.; Serna-Lagunes, R.; Rosas-Saito, G.; Cruz-Romero, A.; Pérez de León, A.A. Morphometrics of Amblyomma mixtum in the State of Veracruz, Mexico. Pathogens 2021, 10, 533. https://doi.org/10.3390/ pathogens10050533

Academic Editor: Olivier Sparagano

Received: 17 March 2021

Accepted: 27 April 2021

Published: 29 April 2021

Publisher's Note: MDPI stays neutral with regard to jurisdictional claims in published maps and institutional affiliations.

Copyright: (c) 2021 by the authors. Licensee MDPI, Basel, Switzerland. This article is an open access article distributed under the terms and conditions of the Creative Commons Attribution (CC BY) license (https:/ / creativecommons.org/licenses/by/ $4.0 /)$.

\begin{abstract}
The tick Amblyomma mixtum is an ectoparasite of veterinary and public health importance because of its role as a vector of zoonotic pathogens. However, little is known about A. mixtum intraspecific variability and if morphological differentiation exists between populations across its geographic range. This study aimed to determine by electron microscopy the morphological variability of A. mixtum populations in the state of Veracruz, which has a large livestock population among states in Mexico. Forty male and 40 female A. mixtum collected from the 10 natural regions of Veracruz state were analyzed microscopically to accomplish main component analysis for each sex. Clusters were calculated with the out-tree method and a dendrogram produced to group the specimens according to their morphometric characteristics. Using 10 main components, $77 \%$ of the morphological variation of the ticks was explained. This is a reflection of scarce intraspecific variation between females. The dendogram for females grouped six clusters of specimens with similar characteristics. Morphometric variability in males was described using eight main components. Limited intraspecific variation was also observed between males. In males, the dendogram yielded six groups with similar morphometric characteristics. Morphometric analyses confirmed that the only species from the Amblyomma cajennense complex that are parasites to livestock in Veracruz state is A. mixtum. The eryxenous nature of $A$. mixtum combined with the frequent movement of livestock hosts may contribute to the apparent homogeneous phenotype of this tick species in Mexico.
\end{abstract}

Keywords: Amblyomma mixtum; tick; morphometrics; cattle; Mexico

\section{Introduction}

Ticks are economically important ectoparasites of livestock [1]. Their economic importance derives from the obligate blood feeding habit and role as vectors of pathogens causing significant morbidity and mortality in host populations [2]. Among the approximately 130 extant tick species in the genus Amblyomma worldwide, several impact livestock health and production as ectoparasitic disease vectors [3,4]. Nearly half of the known Amblyomma species exist in the Americas and in some cases their geographic range is expanding $[5,6]$.

Amblyomma mixtum is a valid species in the A. cajennense species complex and is considered one of the most economically important tick species parasitizing livestock in Mexico [7,8]. Its impact on livestock health is amplified by the role of A. mixtum as a mechanical vector of Anasplasma that causes bovine anaplasmosis, which can result in significant mortality among cattle herds, it also parasitizes horses, being an important 
vector of various species of rickettsiae [9]. Moreover, the public health importance of A. mixtum stems from its host range that includes humans, and ability to vector zoonotic pathogens [10]. As it is the case with other Amblyomma species in Mexico [11], there are biological aspects of $A$. mixtum that remain to be defined.

Veracruz is a state in Mexico with a diverse livestock population and the largest cattle herd comprising approximately $11 \%$ of the total national inventory $[12,13]$. Syntethic acaricides are used to control ticks infesting livestock including A. mixtum. The indiscriminate use of acaricides is a major driver for the emergence of acaricide resistance among populations of A. mixtum infesting livestock in Veracruz state [14]. This is concerning because evidence for the emergence of resistance to multiple classes of acaricides is in this three-host tick species even when gene flow associated with lack of genetic differentiation was documented for A. mixtum populations in the same region [15]. However, studies to determine if morphological variation among A. mixtum population in Veracruz state remained to be conducted.

Morphological anomalies associated with exposure to acaricides was reported for Amblyomma lepidum infesting cattle in Uganda [16]. This prompted morphological analysis of our tick collection to determine if a similar situation occurred in A. mixtum. Here, we report the morphometrics of A. mixtum collected from infested livestock and the surrounding agroecosystems representing the ten ecological regions in the state of Veracruz, Mexico.

\section{Results}

Based on the results of the descriptive statistics of the morphological characters evaluated, it is observed that the males surpassed the females in terms of the dimensions of the CB, TL, LSII, HL, HW and Tal characters, in the remaining morphometric characters, both males and females did not show evident morphological differentiation (Table 1).

Table 1. Descriptive statistics (mean and standard deviation) of the morphometry of $A$. mixtum by sex category, scutum length (SL), scutum width (SW), dorsal capitulum breadth (CB), dorsal capitulum length (CL), basis capituli ventral length (VL), palpi total length (TL), length segment I (LSI), length segment II (LSII), length segment III (LSIII), width segment I (WSI), width segment II (WSII), width segment III (WSIII), hypostome length (HL), hypostome width (HW), tarsi length (TaL), tarsi width (TW). The average values and their standard deviation obtained from the components that analyze the morphometric variation of A. mixtum are shown.

\begin{tabular}{|c|c|c|c|c|c|c|c|c|c|c|c|c|c|c|c|c|c|}
\hline Sex & Statistic & CB & CL & VL & TL & LSI & LSII & LSIII & WSI & WSII & WSIII & HL & HW & TaL & TW & SL & SW \\
\hline q & $\begin{array}{l}\text { Mean } \\
\text { SD }\end{array}$ & $\begin{array}{c}0.5 \\
0.04\end{array}$ & $\begin{array}{c}0.4 \\
0.03\end{array}$ & $\begin{array}{c}0.3 \\
0.03\end{array}$ & $\begin{array}{l}0.7 \\
0.1\end{array}$ & $\begin{array}{c}0.1 \\
0.01\end{array}$ & $\begin{array}{c}0.5 \\
0.04\end{array}$ & $\begin{array}{c}0.2 \\
0.03\end{array}$ & $\begin{array}{c}0.1 \\
0.01\end{array}$ & $\begin{array}{c}0.1 \\
0.01\end{array}$ & $\begin{array}{c}0.2 \\
0.02\end{array}$ & $\begin{array}{c}0.7 \\
0.03\end{array}$ & $\begin{array}{c}0.2 \\
0.01\end{array}$ & $\begin{array}{c}0.7 \\
0.03\end{array}$ & $\begin{array}{c}0.2 \\
0.01\end{array}$ & & \\
\hline $0^{x}$ & $\begin{array}{l}\text { Mean } \\
\text { SD }\end{array}$ & $\begin{array}{c}0.7 \\
0.02\end{array}$ & $\begin{array}{c}0.4 \\
0.02\end{array}$ & $\begin{array}{c}0.3 \\
0.02\end{array}$ & $\begin{array}{c}0.9 \\
0.03\end{array}$ & $\begin{array}{c}0.1 \\
0.02\end{array}$ & $\begin{array}{c}0.6 \\
0.02\end{array}$ & $\begin{array}{c}0.2 \\
0.02\end{array}$ & $\begin{array}{c}0.1 \\
0.01\end{array}$ & $\begin{array}{c}0.1 \\
0.01\end{array}$ & $\begin{array}{c}0.2 \\
0.02\end{array}$ & $\begin{array}{c}0.9 \\
0.03\end{array}$ & $\begin{array}{c}0.3 \\
0.02\end{array}$ & $\begin{array}{c}0.9 \\
0.04\end{array}$ & $\begin{array}{c}0.2 \\
0.03\end{array}$ & $\begin{array}{l}1.9 \\
0.2\end{array}$ & $\begin{array}{l}1.9 \\
0.1\end{array}$ \\
\hline
\end{tabular}

Based on the morphometric measurements, the females were grouped into three groups, the first made up of three individuals, the second by 12 and the last group was made up of a greater number of females that were more homogeneous morphologically (Figure 1).

Regarding the males, two individuals (35 and 40 individual) did not show similarities in the morphometric characteristics of the group made up of the rest ( $n=38$ individuals), which were grouped by the similarity of its morphometric features (Figure 2). 


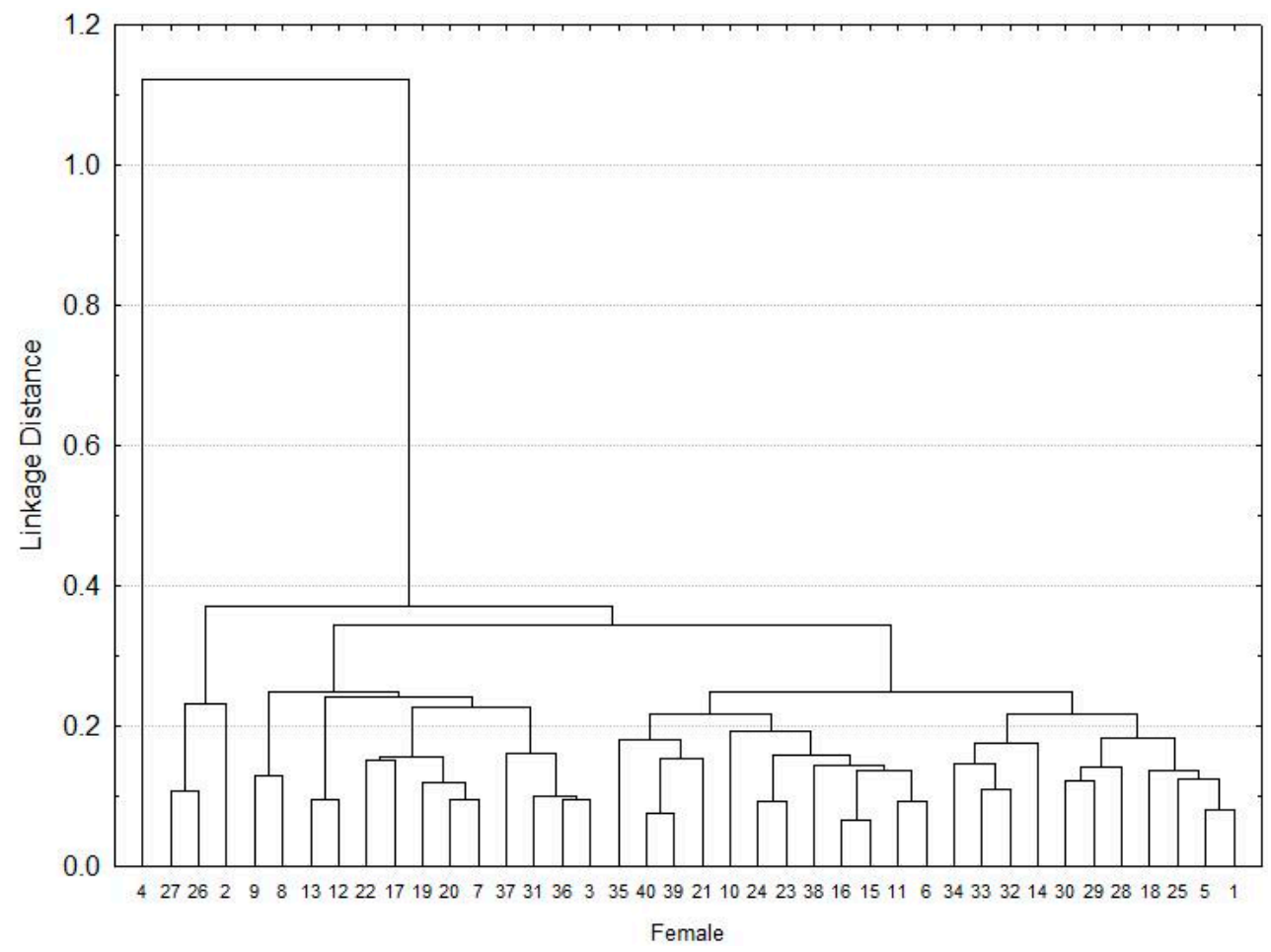

Figure 1. Cluster of the morphometry for A. mixtum females.

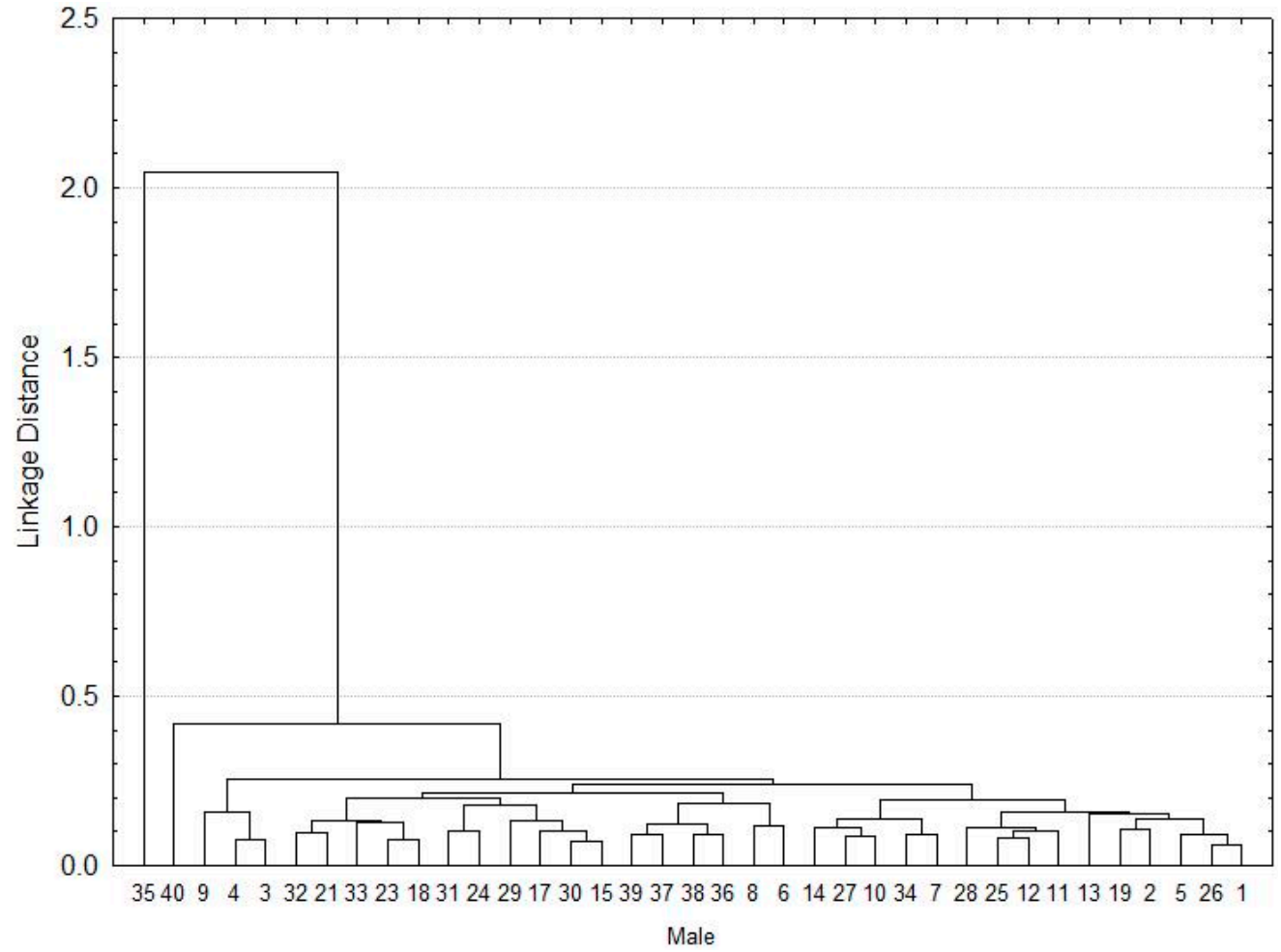

Figure 2. Cluster of the morphometry for A. mixtum males.

\section{Discussion}

This is the first study to interrogate A. mixtum intraspecific variability and morphological differentiation between populations in Mexico. Results of the morphometric analyses confirmed that the only species from the A. cajennense complex parasiting cattle in Veracruz state, Mexico is A. mixtum. This is in agreement with results from previous studies on the 
reinstatement of $A$. mixtum as a valid species and the documentation of its geographic range $[7,15,17]$. It is important to understand the actual distribution of $A$. mixtum because of its relevance in veterinary medicine and public health as an ectoparasite and vector of tick-borne pathogens [6,18].

Evidence recognizing $A$. mixtum as an important ectoparasitic disease vector of vertebrate hosts in Veracruz state continues to accumulate. This tick species was formerly referred to as $A$. cajennense $[11,19,20]$. The genetic plasticity of $A$. mixtum is reflected in its adaptation to infest the water buffalo [12], which is a livestock species introduced to Mexico [21]. Resistance to multiple classes of acaricides among populations of $A$. mixtum infesting livestock in Veracruz state was confirmed [14].

The A. mixtum analyzed in this study were sampled in parts of Veracruz state where livestock are treated intensely with acaricides [14,22].

However, we did not detect morphological anomalies associated with exposure to acaricides as it was reported for Amblyomma lepidum infesting cattle in Uganda [16]. Morphological abnormalities have been reported in several Amblyomma species [5]. Their detection in field-collected $A$. mixtum likely requires a larger samples collection because morphological anomalies apparently rarely occur [16].

Intraspecific morphological variation was not detected in the male and female A. mixtum analyzed in this study. This seemingly homogenous phenotype may reflect the lack of genetic separation between $A$. mixtum populations across the natural regions of Veracruz state [15]. Although it can inhabit diverse ecosystems in Mexico parasitizing multiple vertebrate host species $[8,23,24]$, similar morphometric characteristics were detected in adult $A$. mixtum. The eryxenous nature of $A$. mixtum combined with the frequent movement of livestock hosts may contribute to the apparent homogeneous phenotype of this tick species in Veracruz state, Mexico.

\section{Materials and Methods}

\subsection{Study Area}

The study was carried out in the state of Veracruz; it is located in eastern Mexico and extends along the coastal plain between the Sierra Madre Oriental and the Gulf of Mexico covering an area of $72,410 \mathrm{~km}^{2}$. Although located in the tropics, the state encompasses these diverse climates given its varied geography [25].

Warm humid and subhumid climate. It comprises a larger area, approximately $80 \%$ of the territory of Veracruz, which is distributed in the coastal plains of the North Gulf and South Gulf, at a maximum height of $1000 \mathrm{~m}$ a.s.l. The average annual temperature is $22-26{ }^{\circ} \mathrm{C}$.

Humid semi-warm climate: In places with an average elevation of 1000 to $1600 \mathrm{~m}$ a.s.l., the physical characteristics favor the development of semi-warm climates. The average temperature varies between 18 and $22^{\circ} \mathrm{C}$.

Temperate climate: It is registered in the zones with altitudes between 1600 and $2800 \mathrm{~m}$ a.s.l.

The ten natural regions are: Huasteca Alta, Huasteca Baja, Totonaca, Nautla, Capital, Sotavento, Mountains, Papaloapan, Tuxtlas, and Olmeca [26].

\subsection{Sampling}

Ticks were sampled between August 2014 and January 2015. Tick samples were collected at livestock production units in municipalities encompassing the ten natural state regions (Figure 3).

Livestock production units where the ticks were sampled were located in these municipalities: Pánuco (N 22 $4^{\prime} 18.664^{\prime \prime}$, W $98^{\circ} 10^{\prime} 56.038^{\prime \prime}$ ), Tampico Alto (N $22^{\circ} 6^{\prime} 53.392^{\prime \prime}$,

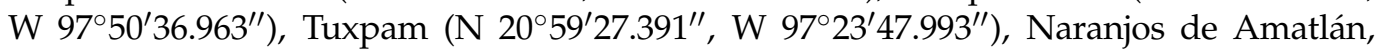

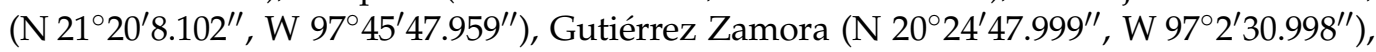

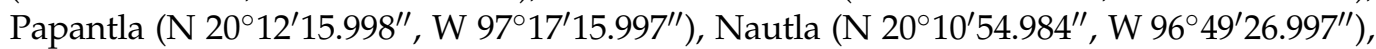

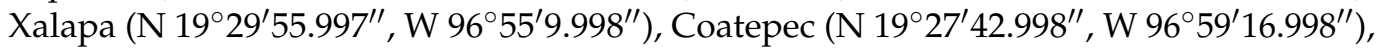
Yanga (N 18 $\left.48^{\prime} 9.18^{\prime \prime}, \mathrm{W} 96^{\circ} 45^{\prime} 32.997^{\prime \prime}\right)$, Orizaba (N 18 $\left.52^{\prime} 16^{\prime \prime}, \mathrm{W} 97^{\circ} 5^{\prime} 22.999^{\prime \prime}\right)$, Cosco-

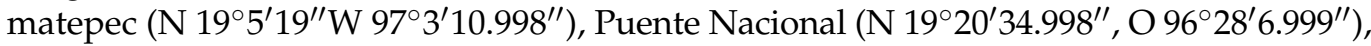


Medellín (N 18 $\left.51^{\prime} 56.999^{\prime \prime}, \mathrm{W} 96^{\circ} 17^{\prime} 24.997^{\prime \prime}\right)$, Soledad de Doblado, (N 19 $3^{\prime} 46.998^{\prime \prime}$,

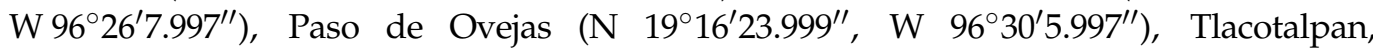
(N 18 $\left.36^{\prime} 53.197^{\prime \prime}, \mathrm{W} 95^{\circ} 40^{\prime} 13.727^{\prime \prime}\right)$, Tierra Blanca (N $\left.18^{\circ} 27^{\prime} 0.288^{\prime \prime}, \mathrm{W} 96^{\circ} 22^{\prime} 54.004^{\prime \prime}\right)$, Ignacio

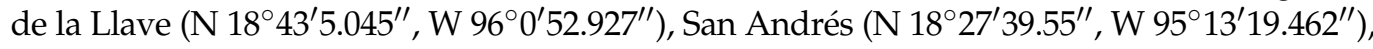
Catemaco (N 18 $\left.30^{\prime} 5.256^{\prime \prime}, \mathrm{W} 95^{\circ} 1^{\prime} 51.65^{\prime \prime}\right)$, Santiago Tuxtla (N $\left.18^{\circ} 28^{\prime} 3.562^{\prime \prime}, \mathrm{W} 95^{\circ} 17^{\prime} 31.855^{\prime \prime}\right)$, Acayucan (N $\left.18^{\circ} 6^{\prime} 43.218^{\prime \prime}, \mathrm{W} 95^{\circ} 6^{\prime} 24.004^{\prime \prime}\right)$, San Juan Evangelista (N 17 $52^{\prime} 31.267^{\prime \prime}$, $\left.\mathrm{W} 95^{\circ} 7^{\prime} 26.936^{\prime \prime}\right)$ and Jesús Carranza (N $17^{\circ} 22^{\prime} 1.852^{\prime \prime}$, W $\left.95^{\circ} 0^{\prime} 37.908^{\prime \prime}\right)$.

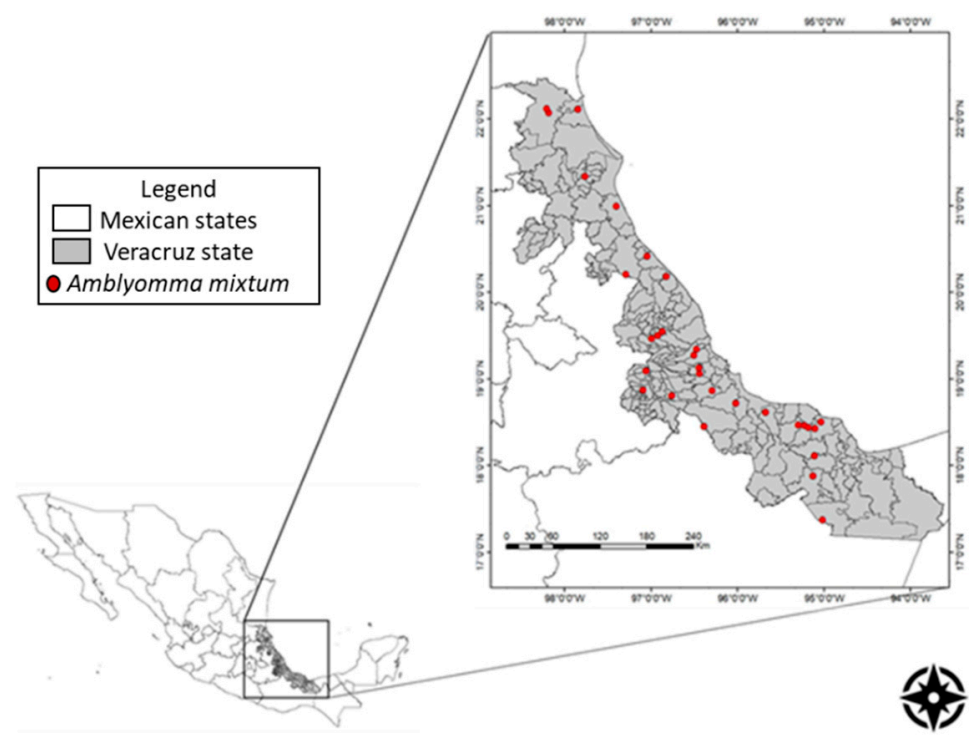

Figure 3. Map of Veracruz state in Mexico with the location of livestock production units within municipalities representing the ten natural state regions where ticks where collected.

\subsection{Tick Collection from Infested Livestock}

Cattle and horses at the livestock production units were inspected visually and manually from head to tail to ascertain tick infestation. When detected, ticks were detached by gentle traction movement of the fingers to avoid rupture of the gnathosoma. Tick samples were stored in a vial correctly coded that contained $70 \%$ ethanol. Vials with the tick samples were taken to the Laboratory of Parasitology in the Torreon del Molino Diagnostic Unit of the Veracruz State University College of Veterinary Medicine in Veracruz, Veracruz. Table 2 lists the sex and number of $A$. mixtum adult ticks collected from livestock hosts sampled at different municipalities in Veracruz state, Mexico.

\subsection{Morphological Identification of Ticks}

Ticks sampled were placed on a slide with the help of small tweezers. Morphological characteristics were observed using a Motic ${ }^{\circledR}$ stereoscope microscope with a camera Moticam 1000 (Speed Fair, Hong Kong, China). Ticks were identified using morphological keys $[11,27,28]$. Males and females were counted and separated for further processing. Table 2 summarizes the sex and number of $A$. mixtum adult ticks collected from livestock hosts at the different municipalities sampled.

\subsection{Scanning Electron Microscopic Analysis}

Ticks identified as $A$. mixtum were inspected for quality control to ensure processing for scanning electron microscopy. Two female and two male $A$. mixtum representing each state region were processed to obtain dorsal and ventral views. Tick samples were cleaned using extra fine Dumont ${ }^{\circledR}$ Antimagnetic-E tweezers and micro spatulas. Once all the dirty material was removed from the ticks, they were cleaned with a micro brush number 5 . Each tick was stored in a white bake lite cap glass vial with $70 \%$ ethanol. 
Table 2. Sex and number of $A$. mixtum adult ticks collected from livestock hosts sampled at different municipalities in Veracruz state, Mexico.

\begin{tabular}{|c|c|c|c|}
\hline \multicolumn{2}{|c|}{ Number of Ticks } & \multirow{2}{*}{ Livestock Host } & \multirow{2}{*}{ Municipality } \\
\hline $0^{x}$ & q & & \\
\hline 2 & 2 & Bos taurus & Pánuco \\
\hline 1 & 2 & Equus caballus & Pánuco \\
\hline 1 & & Equus caballus & Tampico Alto \\
\hline 2 & 2 & Bos taurus & Tuxpam \\
\hline 2 & 2 & Equus caballus & Naranjos Amatlán \\
\hline 2 & 2 & Bos taurus & Gutiérrez Zamora \\
\hline \multirow[t]{2}{*}{2} & 1 & Equus caballus & Gutiérrez Zamora \\
\hline & 1 & Equus caballus & Papantla \\
\hline 2 & 2 & Bos taurus & Nautla \\
\hline 2 & 2 & Equus caballus & Nautla \\
\hline 2 & 2 & Bos taurus & Xalapa \\
\hline \multirow[t]{2}{*}{2} & 1 & Equus caballus & Xalapa \\
\hline & 1 & Equus caballus & Coatepec \\
\hline \multirow[t]{3}{*}{2} & & Bos taurus & Yanga \\
\hline & 1 & Equus caballus & Yanga \\
\hline & 1 & Bos taurus & Orizaba \\
\hline \multirow[t]{2}{*}{2} & 1 & Equus caballus & Coscomatepec \\
\hline & 1 & Bos taurus & Coscomatepec \\
\hline \multirow[t]{2}{*}{1} & 1 & Bos taurus & Puente Nacional \\
\hline & 1 & Equus caballus & Puente Nacional \\
\hline \multirow[t]{2}{*}{1} & & Bos taurus & Medellín \\
\hline & 1 & Bos taurus & Soledad de Doblado \\
\hline \multirow{2}{*}{1} & & Equus caballus & Soledad de Doblado \\
\hline & 1 & Equus caballus & Paso de Ovejas \\
\hline 2 & & Bos taurus & Tlacotalpan \\
\hline \multirow[t]{4}{*}{1} & 1 & Equus caballus & Tlacotalpan \\
\hline & 1 & Bos taurus & Tierra Blanca \\
\hline & 1 & Equus caballus & Tierra Blanca \\
\hline & 1 & Bos taurus & Ignacio de la Llave \\
\hline 1 & & Equus caballus & Ignacio de la Llave \\
\hline 1 & 2 & Bos taurus & San Andrés \\
\hline 1 & & Equus caballus & San Andrés \\
\hline \multirow[t]{2}{*}{1} & & Bos taurus & Catemaco \\
\hline & 2 & Equus caballus & Catemaco \\
\hline 1 & & Equus caballus & Santiago Tuxtla \\
\hline 1 & 1 & Bos taurus & Acayucan \\
\hline 1 & 1 & Equus caballus & Acayucan \\
\hline 1 & 1 & Bos taurus & San Juan Evangelista \\
\hline \multirow[t]{2}{*}{1} & & Equus caballus & San Juan Evangelista \\
\hline & 1 & Equus caballus & Jesús Carranza \\
\hline
\end{tabular}

Sample downstream processing was done according to Dixon et al. (2000) with some modifications. Briefly, ticks previously stored in $70 \%$ ethanol underwent two ultrasonic cleanings for 5 min each using a Cole-Parmer ${ }^{\circledR} 8848$ ultrasonic cleaner. For dehydration, the $70 \%$ ethanol was replaced with $90 \%$ ethanol. After $90 \mathrm{~min}$ in $90 \%$ ethanol, ticks were placed in 100\% ethanol three times for 30 min each. Thereafter, the ticks were placed in xylene and maintained at a temperature of $40{ }^{\circ} \mathrm{C}$ for $24 \mathrm{~h}$. Then, they were subjected to three washes of $30 \mathrm{~min}$ each with absolute ethanol, which was followed by critical point drying with a dryer Quorum ${ }^{\circledR}$ model $\mathrm{K} 850$ where the ethanol was exchanged for $\mathrm{CO}_{2}$. Once the ticks were completely dry and ethanol free, they were placed in the desired position on a polished aluminum stub covered by a conductive carbon adhesive tape. All the ticks were then coated with gold by the "sputter coating" method using the Coater Quorum ${ }^{\circledR}$ model Q150R S. All the samples were analyzed using the scanning electron microscope FEI Quanta 250 FEG (Oregon, USA). 


\subsection{Morphometrics}

Morphometric relationships were evaluated separately for males (Figure 2) and females (Figures 4 and 5). Sixteen morphological variables were analyzed for females and 14 for males, where we do not include the scutum (letters of the alphabet associated with the principal components in Table 1). These included: (1) scutum length (SL), (2) scutum width (SW), (3) dorsal capitulum breadth (CB), (4) dorsal capitulum length (CL), (5) basis capituli ventral length (VL), (6) palpi total length (TL), (7) length segment I (LSI), (8) length segment II (LSII), (9) length segment III (LSIII), (10) width segment I (WSI), (11) width segment II (WSII), (12) width segment III (WSIII), (13) hypostome length (HL), (14) hypostome width (HW), (15) tarsi length (TL), (16) tarsi width (TW).
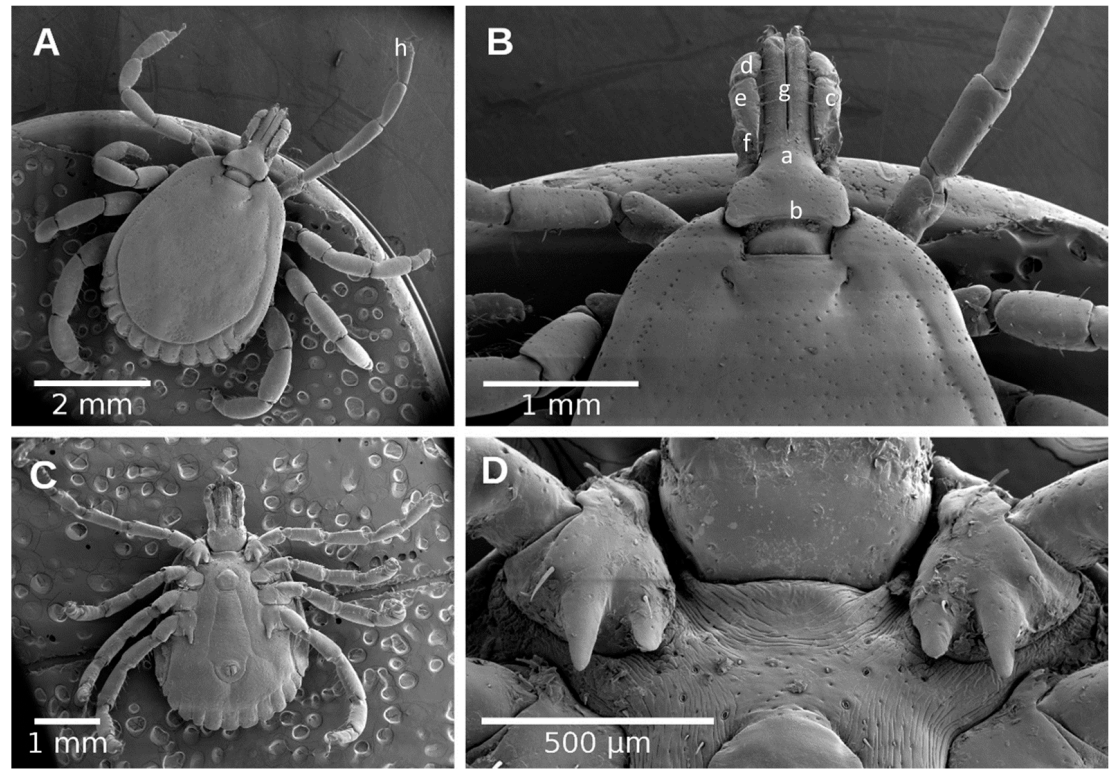

Figure 4. Male of Amblyomma mixtum. (A) Dorsal view; (B) Dorsal view of capitulum; (C) Ventral view; (D) Ventral view of capitulum. (a) capitulum; (b) basis capitulum; (c) palpi; (d) palpi segment I; (e) palpi segment II; (f) palpi segment III; (g) hypostome; (h) tarsi.
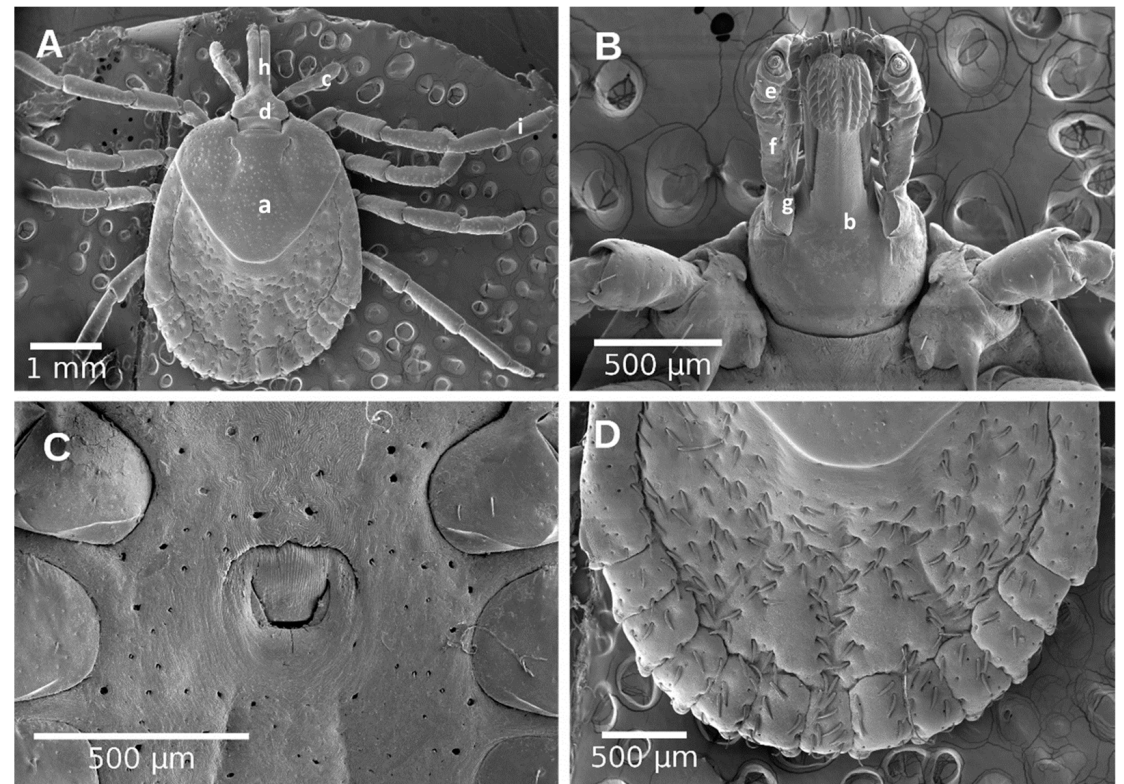

Figure 5. Female of Amblyomma mixtum. (A) Dorsal view; (B) Ventral view of capitulum; (C) Genital aperture; (D) fentoons; (a) scutum; (b) capitulum; (c) basis capitulum; (d) palpi; (e) palpi segment I; (f) palpi segment II; (g) palpi segment III; (h) hypostome; (i) tarsi. 
Arithmetic Averages (UPGMA) clustering was used to perform the Unweighted Pair Group Method. Results were displayed through Principal Component Analysis (PCA). PCA was used to further define the clusters, and to evaluate the contributions of individual characters to the phenetic differences among clusters. Eigenvectors were extracted from a pair-wise matrix of Pearson product-moment correlations of the characters. A phenogram (UPGMA) was constructed using the distance matrix. All statistical analyses were done using SAS 9.0.

Author Contributions: Data curation, R.S.-L. and G.R.-S.; Formal analysis, M.A.-D. and R.S.-L.; Funding acquisition, D.R.-S.; Investigation, M.A.-D., D.R.-S. and A.A.P.d.L.; Methodology, S.S.-M., R.S.-L., G.R.-S. and A.C.-R.; Project administration, D.R.-S.; Writing—original draft, M.A.-D.; Writingreview \& editing, S.S.-M., A.C.-R. and A.A.P.d.L. All authors have read and agreed to the published version of the manuscript.

Funding: This research was supported in part through agreement with the USDA-ARS KniplingBushland U.S. Livestock Insects Research Laboratory, Kerrville, TX related to appropriated project 309432000-039-00-D. The authors report no financial or commercial conflicts of interest. Mariel AguilarDomínguez was supported by a PhD fellowship from CONACyT and is a doctoral student of the Program of Doctorado en Ciencias Agropecuarias, Universidad Veracruzana, UV.

Institutional Review Board Statement: Not applicable.

Informed Consent Statement: Not applicable.

Acknowledgments: We thank the cattle producers for their collaboration, and we are also grateful to the staff of the Parasitology Laboratory of the Veterinary School of the University of Veracruz and the undergraduate students for their support to accomplish this study. The USDA is an equal opportunity provider and employer.

Conflicts of Interest: The authors declare no conflict of interest.

\section{References}

1. Estrada-Peña, A. Ticks as vectors: Taxonomy, biology and ecology. Rev. Sci. Tech. 2015, 34, 53-65. [CrossRef] [PubMed]

2. Adalberto, A.; Pérez de León, R.D.; Mitchell-Miller, R.; Lohmeyer, K. Advances in integrated tick Management research for area-wide mitigation of tick-borne disease Burden. In Area-Wide Integrated Pest Management. Development and Field Application, 1st ed.; Hendrichs, J., Pereira, R., Vreysen, M.J.B., Eds.; Routledge and CRC Press: Boca Raton, FL, USA, $2021 ;$ pp. $251-274$.

3. Gondard, M.; Cabezas-Cruz, A.; Charles, R.A.; Vayssier-Taussat, M.; Albina, E.; Moutailler, S. Ticks and Tick-Borne Pathogens of the Caribbean: Current Understanding and Future Directions for More Comprehensive Surveillance. Front. Cell. Infect. Microbiol. 2017, 7, 490. [CrossRef]

4. Enríquez, S.; Guerrero, R.; Arrivillaga-Henríquez, J.; Araujo, P.; Villacrés, E.; Enríquez, A.; Benítez-Ortíz, W. New records of ticks of genus Amblyomma Koch, 1844 (Acari: Ixodidae) for Ecuador. Acta Parasitol. 2020, 65, 430-440. [CrossRef] [PubMed]

5. Molaei, G.; Karpathy, S.E.; Andreadis, T.G. First Report of the Introduction of an Exotic Tick, Amblyomma coelebs (Acari: Ixodidae), Feeding on a Human Traveler Returning to the United States from Central America. J. Parasitol. 2019, 105, 571-575. [CrossRef] [PubMed]

6. Pascoe, E.L.; Marcantonio, M.; Caminade, C.; Foley, J.E. Modeling Potential Habitat for Amblyomma Tick Species in California. Insects 2019, 10, 201. [CrossRef]

7. Nava, S.; Beati, L.; Labruna, M.B.; Cáceres, A.G.; Mangold, A.J.; Guglielmone, A.A. Reassessment of the taxonomic status of Amblyomma cajen-nense (Fabricius, 1787) with the description of three new species, Amblyomma tonelliae n. sp., Amblyomma interandinum n. sp. and Amblyomma patinoi n. sp., and reinstatement of Amblyomma mixtum Koch, 1844, and Amblyomma sculptum Berlese, 1888 (Ixodida: Ixodidae). Ticks Tick Borne Dis. 2014, 5, 252-276.

8. Piña, F.T.B.; Rodrigues, V.D.S.; Higa, L.D.O.S.; Garcia, M.V.; Barros, J.C.; De León, A.A.P.; Andreotti, R. Life cycle of Amblyomma mixtum (Acari: Ixodidae) parasitizing different hosts under laboratory conditions. Exp. Appl. Acarol. 2017, 73, 257-267. [CrossRef]

9. Almazan, C.; Tipacamu, G.A.; Rodriguez, S.; Mosqueda, J.; Perez de Leon, A. Immunological control of ticks and tick-borne diseases that impact cattle health and production. Front. Biosci. 2018, 23, 1535-1551. [CrossRef]

10. Rodríguez-Vivas, R.; Apanaskevich, D.; Ojeda-Chi, M.; Trinidad-Martínez, I.; Reyes-Novelo, E.; Esteve-Gassent, M.; de León, A.P. Ticks collected from humans, domestic animals, and wildlife in Yucatan, Mexico. Veter. Parasitol. 2016, 215, 106-113. [CrossRef]

11. Guzmán-Cornejo, C.; Robbins, R.; Guglielmone, A.A.; Montiel-Parra, G.; Pérez, T.M. The Amblyomma (Acari: Ixodidae) of Mexico: Identification keys, distribution and hosts. Zootaxa. 2011, 2998, 16-38. [CrossRef]

12. Aguilar-Dominguez, M.; Romero-Salas, D.; Sánchez-Montes, S.; Barradas-Piña, F.; Rosas, G.; Cruz-Romero, A.; Ibarra-Priego, N.; Becker, I.; Lohmeyer, K.H.; de León, A.P. Ocurrence of Amblyomma mixtum on the water buffalo (Bubalus bubalis) in Mexico. Int. J. Parasitol. Parasites Wildl. 2018, 7, 405-408. [CrossRef] [PubMed] 
13. Pérez, C.; Zavaleta, L. Traditional livestock of the north of the state of Veracruz. Nacameh 2019, 13, 25-36. [CrossRef]

14. Higa, L.D.O.S.; Piña, F.T.B.; Rodrigues, V.D.S.; Garcia, M.V.; Salas, D.R.; Miller, R.J.; de Leon, A.P.; Barros, J.C.; Andreotti, R. Evidence of acaricide resistance in different life stages of Amblyomma mixtum and Rhipicephalus microplus (Acari: Ixodidae) collected from the same farm in the state of Veracruz, Mexico. Prev. Veter. Med. 2020, 174, 104837. [CrossRef]

15. Aguilar-Domínguez, M.; Sánchez-Montes, S.; Esteve-Gassent, M.D.; Barrientos-Salcedo, C.; de León, A.P.; Romero-Salas, D. Genetic structure analysis of Amblyomma mixtum populations in Veracruz State, Mexico. Ticks Tick Borne Dis. 2019, 10, 86-92. [CrossRef]

16. Balinandi, S.; Mugisha, L.; Bbira, J.; Kabasa, W.; Nakayiki, T.; Bakkes, D.K.; Lutwama, J.J.; Chitimia-Dobler, L.; Malmberg, M. General and Local Morphological Anomalies in Amblyomma lepidum (Acari: Ixodidae) and Rhipicephalus decoloratus Infesting Cattle in Uganda. J. Med. Ėntomol. 2019, 56, 873-877. [CrossRef]

17. Beati, L.; Nava, S.; Burkman, E.J.; Barros-Battesti, D.M.; Labruna, M.B.; A Guglielmone, A.; Cáceres, A.G.; Guzmán-Cornejo, C.M.; León, R.; A Durden, L.; et al. Amblyomma cajennense (Fabricius, 1787) (Acari: Ixodidae), the Cayenne tick: Phylogeography and evidence for allopatric speciation. BMC Evol. Biol. 2013, 13, 267. [CrossRef] [PubMed]

18. Rivera-Páez, F.A.; Labruna, M.B.; Martins, T.F.; Perez, J.E.; Castaño-Villa, G.J.; Ossa-López, P.A.; Gil, C.A.; Sampieri, B.R.; Aricapa-Giraldo, H.J.; Camargo-Mathias, M.I. Contributions to the knowledge of hard ticks (Acari: Ixodidae) in Colombia. Ticks Tick Borne Dis. 2018, 9, 57-66. [CrossRef] [PubMed]

19. Illoldi-Rangel, P.; Rivaldi, C.-L.; Sissel, B.; Fryxell, R.T.; Gordillo-Pérez, G.; Rodríguez-Moreno, A.; Williamson, P.; Montiel-Parra, G.; Sánchez-Cordero, V.; Sarkar, S. Species Distribution Models and Ecological Suitability Analysis for Potential Tick Vectors of Lyme Disease in Mexico. J. Trop. Med. 2012, 2012, 1-10. [CrossRef]

20. Sosa-Gutierrez, C.G.; Vargas-Sandoval, M.; Torres, J.; Gordillo-Pérez, G. Tick-borne rickettsial pathogens in questing ticks, removed from humans and animals in Mexico. J. Veter. Sci. 2016, 17, 353-360. [CrossRef]

21. Romero-Salas, D.; Mira, A.; Mosqueda, J.; García-Vázquez, Z.; Hidalgo-Ruiz, M.; Vela, N.A.O.; de León, A.A.P.; Florin-Christensen, M.; Schnittger, L. Molecular and serological detection of Babesia bovis- and Babesia bigemina-infection in bovines and water buffaloes raised jointly in an endemic field. Veter. Parasitol. 2016, 217, 101-107. [CrossRef] [PubMed]

22. Alonso-Díaz, M.; Fernández-Salas, A.; Martínez-Ibáñez, F.; Osorio-Miranda, J. Amblyomma cajennense (Acari: Ixodidae) tick populations susceptible or resistant to acaricides in the Mexican Tropics. Veter. Parasitol. 2013, 197, 326-331. [CrossRef] [PubMed]

23. Almazán, C.; Torres-Torres, A.; Torres-Rodríguez, L.; Soberanes-Céspedes, N.; Ortiz-Estrada, M. Aspectos biológicos de Amblyomma mixtum (Koch, 1844) en el noreste de México. Quehacer Científico en Chiapas 2016, 2, 10-19.

24. Coronel-Benedett, K.C.; Ojeda-Robertos, N.F.; González-Garduño, R.; Ibañez, F.M.; Rodríguez-Vivas, R.I. Prevalence, intensity and population dynamics of hard ticks (Acari: Ixodidae) on sheep in the humid tropics of Mexico. Exp. Appl. Acarol. 2018, 74, 99-105. [CrossRef]

25. INEGI, Censo de Población y vivienda. Available online: https://www.inegi.org.mx/ (accessed on 25 April 2019).

26. INAFED Instituto para el Federalismo y el Desarrollo Municipal. Available online: https://www.gob.mx/inafed (accessed on 3 April 2019).

27. Álvarez, C.V.; Bonilla, M. Adultos y ninfas de la garrapata Amblyomma cajennense fabricius (acari: Ixodidae) en equinos y bovinos. Agronomía Costarricense. 2007, 31, 61-69.

28. Martins, T.F.; Onofrio, V.C.; Barros-Battesti, D.M.; Labruna, M.B. Nymphs of the genus Amblyomma (Acari: Ixodidae) of Brazil: Descriptions, redescriptions, and identification key. Ticks Tick Borne Dis. 2010, 1, 75-99. [CrossRef] [PubMed] 